\title{
What can the African diaspora contribute to innovation and knowledge creation? The case study of Zimbabwean innovators
}

\author{
Juliet Thondhlana, Roda Madziva and Evelyn Chiyevo Garwe
}

Abstract: The importance of diaspora and transnational knowledge production, innovation, and development is of growing interest, particularly in the developing world. The phenomenal increase in high human capital migration from poor to rich countries has historically led to what is commonly known as brain drain, which has negatively impacted the capacity of such countries to innovate. Yet more recently the emergence of the phenomenon of transnationalism has demonstrated the potential to transform brain drain into brain circulation, for the mutual benefit of both sending and receiving contexts. This article uses the case of Zimbabwe to explore the role of diasporan professionals, scholars, and entrepreneurs in contributing to knowledge production, innovation, and development initiatives in their countries of origin. Zimbabwe is an example of many African countries that have experienced substantial attrition of highly qualified knowledge workers for various reasons. A qualitative approach, involving interviews and documentary evidence, enabled the researchers to engage with the Zimbabwean diaspora to capture their narratives regarding the challenges and opportunities, which were then used to develop successful transnational knowledge production initiatives.

Keywords: Diaspora transnationalism, Zimbabwe, brain drain and brain circulation, country of origin.

(C) The author(s) 2021. This is an open access article licensed under a

Creative Commons Attribution-NonCommercial-NoDerivs 4.0 Unported License 


\section{Introduction}

The dearth of recognised academic knowledge production in Africa has been a subject of many scholarly conversations (Okolie 2003, Zegeye \& Vambe 2006). In this article, we highlight how diaspora transnationalism can contribute to knowledge production in Africa through brain circulation, a process involving the international mobility of highly skilled migrants, whereby they move to study abroad, get employed abroad, and later return home when a good opportunity arises (Johnson \& Regets 1998). This stems from the realisation that most of the literature on African diaspora transnationalism has hitherto focused on diaspora direct investment and engaged less with transnational knowledge and its potential to contribute towards innovation-understood as an 'outcome, a process, and a mindset, where outcomes arise from an innovation process accentuated by mindset' (Kahn 2018: 459) — and development.

Diaspora and transnationalism are fluid concepts that are often confused as well as being used to capture a broader range of international migration phenomena (IOM 2017, Thondhlana \& Madziva 2018). Diaspora is a very old concept, which 'was traditionally used to describe the Jewish population exiled from Judea in biblical times and from British Palestine before the formation of the modern nation-state, Israel' (Tung 2008: 300, Faist 2010). However, in recent years the concept of diaspora has been expanded to capture myriad contemporary forms of international migration, including both forced and voluntary migration, and more broadly migrants who have left their places of birth and have integrated into countries of immigration, but are still maintaining strong ties with their countries of origin (Pasura 2012). Some migrants 'shuttle between host and home countries for opportunities' (Osaghae 2018: 13). Transnationalism, on the other hand, has been defined as 'a process by which migrants, through their daily life activities create social fields that cross national boundaries' (Basch et al. 1994: 22). Thus, as Osaghae (2018: 13) argues, 'the concept of transnationalism was coined to give theoretical form to empirical observation that migrants through their daily activities (social, economic, and political) create activities that cut across national boundaries'. Levitt (2001: 202-3) has therefore argued that 'diasporas form out of the transnational communities spanning sending and receiving countries and out of the real or imagined connections between migrants from a particular homeland who are scattered throughout the world'. More recently Osaghae (2018) has used the term 'diaspora transnationalism' to capture, explain, and understand migrants' diverse activities, which span borders. Among these activities is the global mobility of human talent, especially from the Global South to the Global North, initially conceptualised in the language of 'brain drain' and more recently as 'brain circulation'. We briefly explore these concepts below. 


\section{Brain drain and brain circulation}

Historically the term 'brain drain' has been used to represent a one-way movement of high human capital from developing to developed countries, which has fuelled the race between countries to attract the best and the brightest brains from around the world to enhance the generation of the ideas which can be turned into innovations, goods, and services. As Robertson (2006: 1) argues, the term 'brain drain' derives from the view that:

brains are the basis for a competitive edge in the so-called 'new knowledge economy'. However, it is not just any old brain. Rather, the race is on between countries to attract the best brains from around the world in order to generate the ideas that will in turn lead to innovations, patents and profits.

Thus in a globalised and knowledge-based society and economy, human talent has become increasingly more mobile with nation-states struggling to keep the people who were born and educated within their national boundaries (Tung 2008). Indeed, the literature on brain drain has shown that the departure or emigration of highly skilled migrants, particularly from developing countries to developed countries, deprives a country of its human capital (brain drain), leading to an increase in the human capital level of the receiving country (brain gain) (Robertson 2006, Chand 2019). In particular, the loss of talent from Africa to liberal democratic countries has been widely documented, and in ways that characterise the African diaspora as 'brain drain' (Crush 2002, Boyo 2013, Chand 2016).

Much of the concern, then, is with the movement of the talented and highly skilled from those countries that can least afford to lose them, such as many of the subSaharan African countries, to countries like the United Kingdom, the United States of America, France, and Germany, which seem to act like a magnet by offering better conditions for work and study. This seems particularly unfair if the sending country has invested heavily in the education and training of these students and skilled workers, only to lose them to another country.

A stark example of this was that of Zimbabwe, which in the early 2000s was characterised as a significant 'brain exporter' (Chetsanga \& Muchenje 2003, Chikanda 2005 ) as it was estimated that between 70 and $90 \%$ of all Zimbabwe university graduates had left the country in search of greener pastures. As Chimanikire (2005: 15) argues, 'the brain drain has even assumed political connotations with [the now late and then] President Robert Mugabe accusing Zimbabwe's former colonial ruler Britain of "stealing" medical doctors, nurses and pharmacists from Zimbabwe'.

Overall, the African Union (2016) estimates that about seventy thousand highly skilled professionals emigrate from African every year, with a report by the 
International Monetary Fund (2016) showing a growing number of African migrants in the OECD countries. As Chand (2019: 6) argues:

There are numerous reasons for the emigration of highly educated Africans. These reasons include pull factors such as better salaries, living conditions, and career opportunities overseas, as well push factors, such as poor-quality institutions, lack of infrastructure, corruption, and nepotism in the country of origin (COO).

However, on the other hand, there is increased recognition that the same migratory movements, initially conceptualised as brain drain, can be more appropriately viewed in the context of a 'brain circulation' or 'triangular human talent flow' (Tung 2008, Saxenian 2006). Here the argument is that international migration is not only about 'draining the intellectual elite from a country but enabling the circulation of ideas and expertise (Robertson 2006: 3, Radwan \& Sakr 2018). For Saxenian (2006) brain circulation is a better term to use as it helps capture the dynamics employed by diaspora communities as they take steps to engage with their COO. In this sense, brain circulation 'does not require that the people involved permanently move back to the $\mathrm{COO}$ rather, it involves being constantly engaged with the $\mathrm{COO}$, so that the benefits of immigration are available to both countries' (Chand 2019: 8). Therefore, 'brain circulation replaces the traditional concepts of brain drain versus brain gain because of the growing mobility of human talent across international boundaries' (Tung 2008: 298). Tung further observes that Chinese diasporans 'have been dubbed in the Chinese press as "astronauts", i.e., people who shuttle back and forth between two distant hubs' (299). In this way, diaspora communities are seen as an important vehicle for transferring much needed resources, including finance, technology, knowledge, and ideas, to their home countries and thereby contributing to the economic and social development of their countries of origin. The triangular flow of human talent thus leads to a win-win situation as both the recipient and sending countries concurrently benefit from the same human talent pool (299).

Indeed, the connection between migration and development has been acknowledged at the international community level as reflected in the recent global framework agendas. A stark example is the 2030 Agenda for Sustainable Development, which recognises migration as a force for development by highlighting the significance of migrant contributions to inclusive growth and sustainable development in both countries of origin and countries of residence.

Writing in the context of Africa, Kajunju (2013) terms the diaspora 'Africa's secret weapon', noting that many African families increasingly depend on their diaspora communities for support. However, as Siwale (2018: 64) argues, 'much of the diaspora's contribution to development in their $\mathrm{COO}$ has primarily been viewed in terms of remittances that go to support families', yet there is growing research evidence that 
remittances from immigrants substantially contribute toward the establishment and enhancement of entrepreneurial business activity in developing countries (Siwale 2018: 64). Particularly with regards to African diaspora transnationalism, there is further evidence that the African diaspora is fast becoming a key contributor to the continent's economic development as investors and entrepreneurs (see Siwale 2018; see also Boly et al. 2014, Chrysostome \& Molz 2014, ).

Overall, it has been argued that, compared to a typical foreign direct investment (FDI), diaspora investment has a special appeal, as investment decisions of diaspora communities are not entirely driven by economic gains. Among other things, diaspora communities have been noted to have emotional ties to their ancestral homeland (Tung 2008), and increasingly they feel obligated to 'give back' to their communities (Madziva \& Thondhlana 2017) as well as being driven by the possibilities for return to the homeland (Riddle et al. 2010, McGregor 2014, Madziva et al. 2018).

At the same time, many governments have put in place mechanisms to tap into the diaspora capital investments - the Indian and Chinese governments are stark examples (Tung 2004, Saxenian 2006). Boly et al. (2014) also note the establishment of investment incentives and promotion agencies that target the diaspora community as potential investors in some African countries, including Uganda, Ghana, Ethiopia, and Nigeria.

While several studies on African diaspora transnationalism so far have focused on diaspora direct investment (DDI), less is known about diaspora investors as facilitators of transnational knowledge and how this can contribute towards the development of new innovations that benefit both the country of origin $(\mathrm{COO})$ and the country of residence (COR). However, Chand (2016) has shown that Nigeria and Ghana are the two countries with the most active diasporas within Sub-Saharan Africa, a development which he attributes to be a result of the policies of these two countries' governments, which promote dialogue between the governments and their diaspora communities. He cites Nigerian diaspora organisations, which work closely with the Nigerian government to ensure workforce training in industry and academia. He also notes the Ghana Physicians and Surgeons' endeavour in working towards improving health care in Ghana.

Some concrete examples and case studies are often drawn from the Chinese and Indian contexts. For example, in her book The New Argonauts: Regional Advantage in a Global Economy, Saxenian (2006) draws on the examples of Chinese and Indian high-tech immigrants, who after successfully establishing their IT innovations in the USA went ahead to adapt the same innovations in their own COO, clearly evidencing the circulation of knowledge between the country of residence and country of origin. 
Reflecting on the case study of India, Tung (2008) focuses on individuals and provides the example of Sabeer Bhatiya, founder of Hotmail.com, who after receiving an MSc in electrical engineering in the USA, worked for a while before launching Hotmail.com. He later on sold Hotmail.com and moved on to other ventures, including plans to develop a new city, Nanocity, in India that will hopefully 'replicate the vibrance and eco-system of innovation found in the Silicon Valley' (Tung 2008: 301).

Writing in the context of Africa, Chand (2019: 301) notes the need to focus on individual country case studies in order to identify 'what policies actually lead to greater brain circulation, as opposed to brain drain'. This paper contributes to the ongoing debate on diaspora transnationalism by focusing on the case study of Zimbabwe diasporans who are facilitators of transnational knowledge production and asks the following questions: what areas of transnational knowledge and innovations are they active in? What are the drivers of their transnationalism and what challenges do they face? What mechanisms do they employ to engage with the COO and why? What transnational models are operational at national and other levels and what are their merits or limitations? We begin with a brief outline of the emergence of the Zimbabwe diaspora to provide a context for our participants' journeys and lived experiences.

\section{Zimbabwe and the making of a diaspora}

Zimbabwe is rated as having one of the best education systems on the continent of Africa in terms of the quality of its programmes and competitiveness of its graduates on the global labour market (Tevera \& Crush 2003, UNICEF 2011, Garwe \& Thondhlana 2018), and Zimbabwe's economy has long depended on its high human capital dating from colonial times and peaking in postcolonial times prior to the deepening socio-economic and political crises which set in in the late 1990s. As a former British colony, Zimbabwe has an education system, however, whose foundations lie in a discriminatory system that limited black people's access to education by creating school and higher education progression bottlenecks for them. Studies (e.g., Thondhlana et al. 2016, Thondhlana 2020) have noted that such a system created the belief that a successful career (deemed white-collar jobs) could only be attained through the academic route and by white people and a few advantaged blacks. The vocational education route first established by missionaries and then used by the colonial regime to create a semi-skilled black workforce for themselves was highly stigmatised (referred to as blue-collar jobs). That way colonial education came to be highly theoretical, thereby locking its African recipients then and postcolonially in what Thondhlana et al. (2020: 13) term 'an employment-seeking mind-set'. 
Nevertheless, the restrictions created a stronger desire among blacks to seek higher education as the way to upward mobility and the highly sought after colonially styled elitist life which would lead to societal respect and status.

This perception was perpetuated after Zimbabwe's attainment of independence in 1980 despite efforts to make education accessible at all levels to the black majority population. The route to Advanced Level and university was highly competitive with many, otherwise variously gifted, students dropping out at Ordinary Level and below who were often relegated to small-scale farming; unpopular technical and vocational education and training; teaching; nursing; or other less academic routes. Surprisingly, some of our innovators travelled some of these routes. It is important to note here that these colonial and postcolonial perceptions partly account for some of the reported behaviours and attitudes towards potential/emerging local innovations and innovators. McGrath et al. (2017) report that in postcolonial Zimbabwe, an academic degree was a guarantee of a highly paying and rewarding job. However, Zimbabwe's socio-political and economic crises which drastically eroded livelihoods in the mid1990s triggered mass migration offering migration opportunities to all and sundry to better their lives and fulfil lost dreams. Herein are the lived experiences of our innovators framed.

Generally, Mandiyanike (2014) observes that there was a love-hate relationship between Zimbabwe and its diaspora, with the discourse sometimes presenting them negatively as 'enemies of the state'. For example, on the one hand, the then President Robert Mugabe expressed a disdain for the diaspora calling them "Blair's spies" (in the case of those going to live and work in the UK between 1997 and 2007), sell-outs, anti-nationalists, traitors and members of the opposition and thus "agents of regime change" (Mandiyanike 2014: 6). Yet on the other hand, there was an obvious love for the remittances sent by the diaspora which were largely responsible for keeping the country afloat economically.

Such pronouncements, however, would have negatively impacted the ease with which diasporans might decide to actively contribute to knowledge production and development in their home country. However, as time went by, the discourse began to shift to 'these [diasporans] are Zimbabweans ... who one day will bring back vital skills that will transform this country. ... They can't stay there forever' (Mandiyanike 2014: 7). This becomes prophetic when one looks at the emerging patterns of diaspora knowledge contribution, innovation, and development. 


\section{Methodology and the study}

A case study approach was chosen to explore emerging patterns of the Zimbabwe diaspora contribution to knowledge production, innovation, and sustainable development. In this regard as exploratory research, a qualitative approach involving interviews and looking at related documentation was considered appropriate for an in-depth understanding of participants' journeys, practices, and lived experiences. The data was drawn from a bigger project looking at education and employability of the Zimbabwe diaspora and a 'return of talent' initiative run by the Zimbabwe Council for Higher Education (ZIMCHE) and its partners. Specific data for this paper involved in-depth interviewing five individuals, four of whom were diasporans with evidenced knowledge production activity, and one Zimbabwe-based authority with evidenced involvement in leveraging the Zimbabwe diaspora in knowledge creation. Given the complexities of our participants' journeys, the case study approach was deemed appropriate as it allows for an in-depth, yet multifaceted, exploration of the complex aspects of the lived experiences of each case. In addition, researchers considered documents (including media and official reports), relating to these specific cases.

Interviewees were accessed through the three researchers' networks, who are all Zimbabweans and two of whom are Zimbabwean migrants to the UK. As insiders, researchers were acutely aware of some of the sensitivities relating to the Zimbabwean diaspora context. These include some of the traumatic experiences of their journeys and lived experiences both in Zimbabwe (which had led to their migration) and the diaspora and the ensuing challenges of eking out a living, which may lead to mistrust of others, including members of their own communities (Hynes 2003). Establishing trust and building rapport both from shared experience and experience of doing migration research was found critical for research success. Ethics approval for both projects was obtained through both the University of Nottingham and ZIMCHE.

Participants were purposefully selected to ensure diversity in activities and approaches. Interviews were audio recorded and transcribed before analysis using thematic and narrative techniques. The narrative approach fitted our theoretical framing and enabled us to tap into participants' lived experiences (McCance et al. 2001) and explore the complexities of their knowledge production journeys. Data analysis included the three researchers examining the data both individually and as a team, with each researcher reading interview transcripts and documents through their own predominant disciplinary lenses, including education, sociology, and migration studies. Interpretations were discussed, with each researcher taking the lead at different points in the iterative process. 


\section{The cases}

Below we provide brief descriptions of the chosen cases.

\section{C1}

$\mathrm{C} 1$ is the story of a high school dropout (at age 15 due to poverty) whose groundbreaking innovative green power (clean energy) has been well received worldwide, taking the world by storm. His remarkable journey started in Zimbabwe where, having dropped out of school, he started experimenting with clean energy. While the country acknowledged his creativity, there was no interest in supporting him financially to make the innovations a reality. His search for support took him to other African countries, but offers came with restrictive and exploitative conditions. His break came when a rich businessman offered him funding without strings attached, which enabled him to migrate to the US where he was able to set up a company for the development of his innovations and where he is now settled. Having realised great success, he is now finding ways to bring his innovations back to Africa where he has so far registered his company in Zimbabwe and another African country. He has more recently developed innovations using his green energy to fight COVID-19, which he hopes can help Africa and the world at large and is already receiving orders from around the world.

$C 2$

$\mathrm{C} 2$ is the story of an academically gifted young man who won a scholarship to study abroad including Cuba, Russia, and eventually the United Kingdom where he attempted to study towards a $\mathrm{PhD}$ but dropped out due to funding problems. This was followed by many years of unemployment during which time he recollected seeing a relative in his native Zimbabwe use an indigenous drink to clean kitchen utensils. He went on to develop biodegradable green cleaning products using this drink as a base that have become a favourite on the market. Following this innovation, he has gone on to investigate many other local Zimbabwe indigenous natural products for use in developing a range of innovative products, including toiletries. In doing this, he engages and partners with communities who share their indigenous solutions and remedies. In turn he pays them for their products as well as contributing to community development projects, such as drilling boreholes to provide clean water and supporting the education of disadvantaged children.

C3

$\mathrm{C} 3$ is the story of a health science innovator who left Zimbabwe despondent after completing Advanced Level, looking for better opportunities to study towards an accounting degree in another African country. Due to lack of funding he ended up 
settling for nursing where he developed an interest in wound care. Following completion of his nursing studies he worked in this African country where his unique talent in wound care was first noticed, thereafter moving to another African country where his talent was further acknowledged, but there were no opportunities for him to further his nursing studies at degree level. In search of better study and employment opportunities he then decided to migrate to the United Kingdom where he got funding to realise his dream of earning Bachelor's and Master's degrees, culminating in an innovative $\mathrm{PhD}$ study in wound care at a top UK Russell Group university. His dream was to patent his innovation and practise in Zimbabwe or another African country. After trying to break into the health systems of four African countries, including Zimbabwe, and failing to navigate their complex processing systems and bureaucratic requirements, despite the critical need for affordable wound care solutions, he ended up patenting the innovation through a UK university. Here his trials have helped many afflicted people who would otherwise have lost their limbs and who have fully recovered. He has since begun to receive many enquiries from afflicted people all over the world and has won many awards for the innovation. He is still seeking opportunities to set up practice in Africa.

\section{C4}

$\mathrm{C} 4$ is the story of an academic who has partnered with African colleagues in higher education and significantly contributed to research, publishing, and policy formulation. C4 left a lectureship job at a Zimbabwe university to look for better livelihoods for her family in the United Kingdom following Zimbabwe's economic downturn. After a three-year period of unemployment she finally got a job at one of the UK's top universities where she got opportunities and support to conduct cutting-age research in higher education and migration. She decided to focus her research on Africa and Zimbabwe so as to benefit her home country and continent. She sought to achieve this through establishing partnerships between her UK university and Zimbabwean universities as well as research collaborations with colleagues from other African countries. To date, she has contributed to the setting up of partnerships with Zimbabwe higher education institutions, the development of a policy framework, library resourcing, and writing for publication in high-impact journals and books, which have benefitted colleagues across Africa.

\section{C5}

C5 is the story of a structured approach to establish and improve partnerships in which Zimbabwean diaspora nationals can support teaching, learning, and research in Zimbabwean higher education institutions. The initiative was in response to the void created by the unprecedented leakages of highly qualified and experienced 
academics and professionals with high-end skills to foreign countries in search of 'greener pastures'. This massive brain drain threatened to negatively impact the quality of education, research, and training in universities. The higher education quality assurance agency, the Zimbabwe Council for Higher Education (ZIMCHE), the Zimbabwe University Vice Chancellors Association (ZUVCA), and the Southern African Regional Universities Association (SARUA) joined hands to address the problem strategically and collaboratively. They resolved to institute a strategy for skills transfer through the temporary return of diaspora lecturers and professionals who would contribute within short periods ranging from four to six weeks.

\section{Findings and discussion}

In this section we present and discuss the three key themes which emerged from the analysis of data including: (1) Africa first: an experience of rejection and unintended brain drain? (2) The diaspora experience and reward of resilience-planned and incidental brain gain? (3) The pull of Africa and brain circulation. The conclusion will provide a discussion of the challenges emerging from the data and propose appropriate models (used here to mean a system or pattern that can be used as a potential example to follow) to leverage diaspora transnationalism to enhance academic knowledge production.

\section{Africa first: an experience of rejection and unintended brain drain?}

As shown by the existing literature on brain drain (e.g., Radwan \& Sakr 2018, Chand 2019) there are a range of push and pull factors that have motivated Africans to leave their countries. Our participants who left Zimbabwe for various destinations around the world, were mainly driven by Zimbabwe's socio-economic and political crises, which have created a disabling environment for personal and national growth and development. This led to some of the best of Zimbabwe's high human capital to leave in search of better opportunities elsewhere so as to maintain the elitist lifestyle they had become accustomed to. As noted by one C5 higher education leader:

Lecturers lost their income, their pride and their dignity, for example, they were forced to join their students in public transport and in queues for basic commodities. They had skills, they had options so they left the country.

Also highlighted by one C5 temporary returnee:

As lecturers, we were not necessarily better paid but we had a lot of opportunities to better our teaching, research and lives. Most of us had mansions in the affluent suburbs. 
The sanctions imposed on Zimbabwe and its isolation from the international community took a toll on the said opportunities as research and consultancy became a thing of the past.

Often those who left had no time to give notice at work, grabbing whatever opportunity presented itself. Because of this and other push factors, leaving the country was generally considered an act of disloyalty/unpatriotism. As such, there were many pronouncements by government and at workplaces suggesting that they would not be welcomed back. As explained by C4:

My former university was clear about not taking me back should I decide to return to Zimbabwe despite the evidenced benefits to the university of taking me back because I'm considered unpatriotic. You therefore can't help feeling a sense of rejection.

In a different situation some, like $\mathrm{C} 1$, have been pushed to leave because of lack of support of their innovative ideas in the home country. As noted above, C1's groundbreaking green energy generation ideas did not find takers in the context of Zimbabwe. It is interesting that in a show of identification with the continent they try other African countries before thinking of further afield but receive the same treatment. As observed by Fogtman et al. (2020), writing about Ghana's space science and technology innovations, innovations may not be immediately appreciated in contexts of poverty where the gains of spending on research and technology may be overshadowed by the reality of here and now bread and butter issues. However, as in the case of CI and as C3 was to later find, other issues were apparent, including instances of potential exploitation and corruption, such as officials or prominent individuals who would only help if they were given shares in the financial gains. 'Even after winning a tender the awarding official wanted some shares in exchange' (C1). C3 has also reported similar experiences with some politicians saying: 'I was told that we needed to sit down and talk profit.'

For some of our cases they left because of a failure by Zimbabwe to recognise and support their talent and potential. For example, it took years before $\mathrm{C} 1$ decided to leave Zimbabwe after many attempts to secure support for his innovations, noting that:

Zimbabwe assessed the innovation and commended it as the first addition to Zimbabwean $X$ technology since independence and confirmed that it worked. However the project fell away due to lack of funds.

Here we can see that the focus on and veneration of academic qualifications as a basis for career success and upward mobility cultivated in colonial times and perpetuated postcolonially, could account for why $\mathrm{C} 1 \mathrm{did}$ not make as much impact as there would have been in the case of a highly educated person. Instead, some of the senior 
academics he interacted with about his innovative ideas told him that his innovations would not gain any currency because the ideas did not conform with scientific expectations of the West, yet time has proven that the ideas were actually unique, ingenious, and groundbreaking. Such a colonial mentality of thinking that Africans cannot innovate has been well documented in the literature (e.g., Ndlovu-Gatsheni 2015, Mbembe 2016, Thondhlana et al. 2020). The dominant colonial-styled academic model based on the Eurocentric epistemic canon (Mbembe 2016), which arguably fuels negative attitudes towards local knowledge production, perpetuates the colonial dynamics of power and knowledge generation otherwise couched in discourses of coloniality (typically understood to be enduring patterns of power resulting from colonialism). In this regard, Thondhlana et al. (2020: 5) argue that 'Coloniality ... exists in all postcolonial societies in various shapes and forms despite repeated postindependence attempts to reverse its multiple legacies.'

As noted above, colonialism created the perception that Africans had no capacity to create enterprises and therefore focused on pursuing an education that would lead to employment. Therefore $\mathrm{Cl}$ contradicted such perceptions on two fronts: that is, a perceived 'unintelligent person' (as defined by having dropped out of school) actually turning out to be a genius and being innovative/entrepreneurial with potential to become an employer.

The impact of such attitudes is crippling. As $\mathrm{C} 1$ reflects:

There was a time when I was aggrieved because of the way I was treated by my Government then when I started, as well as my fellow countrymen. All I yearned for was encouragement as well as validation by my own people. Encouragement and validation by one's own people are crucial elements whenever one dares to traverse uncharted terrain.

Thus having failed to find an enabling creative space in Zimbabwe, $\mathrm{C} 1$ then tried other African countries who again failed to help patent his innovations 'because they were thought to defy science'. Therefore, $\mathrm{C} 1$ had no other option but to leave for the United States of America. However, it is important to note that, while Africa appeared to be oblivious to the loss of and was pushing away its highly skilled and talented, Western countries such as Australia, Canada, New Zealand, the United States of America, and the United Kingdom were preoccupied with scouting and competing for the 'best and brightest' and designing 'talent for citizenship' regimes. Indeed, schemes or initiatives such as the Highly Skilled Migrant Programme of the United Kingdom and the European Union's Scientific Visa (to attract the highly educated) and the Blue Card (targeting the highly skilled) with permanent residence and citizenship are some of the incentives to attract high human capital (Shachar 2006, Cerna \& Chou 2014).

It is no wonder, then, that our talented participants have found their way to some of these nations where they have found success. The question, however, is of how easily they have found this success and this is the subject of the next section. 


\section{The diaspora experience and reward of resilience_planned and incidental brain gain?}

Talking about the United States of America's acknowledgement and support of his work as well as giving him a home, $\mathrm{C} 1$ expressed 'disappointment that Africa did not see what the US Government saw in my ground breaking inventions'. By this he was referring to the enabling environment including the supportive US laws and policies towards technology and innovations which embrace and support small ideas lacking in other contexts, particularly Africa.

However, while migrant host countries mostly in the developing world are often perceived and pitched as providing an enabling environment for education, career progression, and innovation, this is not without complexities and challenges, and not everyone manages to realise their potential. In this regard, studies (e.g. Erel 2010, Madziva et al. 2014, Thondhlana et al. 2016) have reported the discriminatory labour market practices that in many reported cases exclude particularly highly skilled and other migrants resulting in their delayed or even failed insertion into the labour market, non-transferability of their skills and limited upward mobility. As C4 explains:

Having left Zimbabwe with a good education to PhD level, years of experience and diverse skills I expected to thrive in the UK but the first three years were extremely traumatic for my family. Responses to my applications were curt and I felt that they just looked at my name and where I came from and didn't bother to look at my qualifications (some of which were previously gained at UK institutions), skills and experience.

Similarly C2's years looking for employment without success before he decided to innovate and go into manufacturing and entrepreneurship is another typical example of diaspora experiences:

After failing to complete my PhD due to lack of funding, my family suffered because I was jobless.

Even award-winning innovator C3 struggled to conduct his groundbreaking study due to a lack of funding support (much of the funding for his research was from his meagre salary) and permission to do trials in UK hospitals. He had to be supported by a white person to access patients as he notes:

I had problems gaining access to patients because I was a black person. I had to be supported by a white person to do my trials. It's only when they started seeing the effective results of my innovation that they started trusting me and I was on national TV and in the papers.

In another context, research (e.g., Thondhlana et al. 2016) has shown how insecure immigration status (for example, student visa) limited migrants in their navigation of the host labour market with many ending up in semi-skilled and non-skilled 
employment, resulting in education and career aspirations being unfulfilled. Nevertheless, those who have succeeded have had to exercise resilience and not give up and some engaged in acts of 'reinvention' (Bauder 2006) involving retraining in a new area or making the tough decision to go into entrepreneurship and innovation. This was the case with $\mathrm{C} 2$ who is now a successful innovator and entrepreneur.

While the experiences are traumatic, they are eventually appreciated as necessary steps to success as expressed by $\mathrm{C} 2$ :

But here I am now. With the support I got from my local authority and donor funding I've been able to develop my products and received huge orders which keep me busy and thriving.

Similarly C4 expresses:

I however did not give up and kept applying for jobs and doing short contract work to gain relevant experience. By God's grace my resilience eventually paid off and I couldn't believe it when I got a job at a top university. Now I look back and appreciate all that experience that made me strong even at the workplace today.

$\mathrm{C} 1$ sees the challenges as necessary for future success:

I value the journey that I have travelled and the life lessons I have learnt along the way. I am learning and will continue to learn to the very end.

As has been documented by Thondhlana (2020: 257), success for the Zimbabwe diaspora was mostly realised through 'A combination of dispositions including resourcefulness, opportunistic and pragmatic orientations, traits developed over years of a challenging Zimbabwean existence ... that enable them to maximise on the opportunities the UK context presents them.' The growing tendency of going into entrepreneurship and seeking opportunities between Zimbabwe and the host nation is one of the consequences of reinvention and in some cases serves to inspire innovative ideas and aspirations, as will be discussed in the next section.

\section{The pull of Africa and brain circulation}

Given the factors which motivate the diasporans to leave the home country and the prevailing environment in the homeland, it is at first inconceivable how they can even think of returning let alone want to contribute to development. Yet considering their traumatic experiences in the diaspora, including new forms of discriminatory and racist practices combined with a sense of never quite belonging, it is again conceivable that the mantra there is no place like home is realistic (Santiago 2019). This is a much-debated issue in the literature on transnationalism and belonging (Ehrkamp \& Leitner 2006). This psychological connection with the homeland drives them to main- 
tain ties to and be involved in their countries of origin (Safran 1991). What is certain is that emerging patterns suggest the possibilities that the diasporans are finding themselves constantly in transit between a native land that cannot support them and a rich country that remains alien (irrespective of their settlement status), leading to the formation of types of transnational networks (Kuznetsov 2006). In the context of the Zimbabwe diaspora in the UK, the 'red [British] passport' has become a tool to facilitate transnationalism. As expressed by $\mathrm{C} 4$ :

I have a red passport but I feel much more Zimbabwean than British. The red passport enables me to travel between the UK and Zimbabwe and facilitates my activities.

However, there is more. In their study of transnational entrepreneurship and gender, Thondhlana \& Madziva (2018) noted that diaspora contribution to economic development resulted from a number of factors, such as a pride in and yearning for one's homeland, and a desire to give back and help develop one's country even when faced with negative attitudes towards the contribution. In our study $\mathrm{C} 1$ echoes this sentiment:

I always love AFRICA and I'm proud of being born and raised in Africa. I will surely come back to Zimbabwe where everything started.

Years later his dream came to be realised when he was able to launch his company in Africa (including in Zimbabwe) seeking ways his company might contribute to sustainable development initiatives using his technology. Calling on Zimbabweans of all walks of life to work together and build the nation, $\mathrm{Cl}$ echoes the African Solutions to African Problems mantra noting that: 'There is no one who will come to do that for us. Africa must rise again!'

Similarly, C4 who has realised her dream of contributing towards educational policy and development says:

I have always been drawn to Zimbabwe and Africa despite not always being welcomed. My former university was initially not willing to collaborate with me because I was seen as disloyal having left without notice although there were extenuating circumstances. This has however not deterred me although I've had to work through collaborations with a government department linking me to universities thereby still indirectly benefitting my former university. They still wouldn't take me back though. However, it's like being rejected by a parent, you keep coming back. My Motto is that Zimbabwe is my home and I have to find ways of giving back and uplift my country. A colleague also advised me that if I don't think about my country and work to have it looked at positively by my UK university no one will. I think I've so far achieved this in my small way.

Award-winning innovator C3 has also networked and started giving back:

I wanted to go out, then one day when I got back I would be respected. And I see that happening now, I have been invited now to go back, to present at the University of Zimbabwe. And to present at the Zimbabwe Ezekiel Guti University as well as Africa 
university at the provincial level. Currently I help individuals who approach me but I hope to be able to help in a more effective way and reach out to more people in Zimbabwe and other African countries

In the context of this 'triangular flow of human talent' and 'brain circulation' (Tung 2008: 299), innovator $\mathrm{C} 2$ has decided to see Zimbabwe, not in terms of its failures but potential. He has, however, chosen to work directly with the sources of indigenous knowledges, indigenous communities, to tap into the country's wealth of natural resources in a way that benefits both the innovator and the communities. He says:

I work with communities in Zimbabwe to tap into indigenous knowledges and then give back to the community through buying their products and contributing a proportion of the profit towards community development projects.

Such an approach has been well documented in the literature including knowledge sharing and compensation (Stabinsky \& Brush 1996). In this regard, joint ventures with indigenous communities have been found successful.

C5 demonstrates how engaging the diaspora at national level provides the necessary confidence in the system and country that can encourage the diaspora to contribute or even for some of them to consider returning, as observed by one of the programme's attendees:

When I left Zimbabwe, this university was not yet established. My experiences here during my visit makes this my institution of choice when I return permanently.

Overall our cases show that looking at the diaspora not as brain drain but brain circulation through transnationalism initiatives enables countries to benefit from diverse knowledge systems which in turn can have a decolonial effect as they learn to appreciate each other's indigenous knowledges for mutual benefit. This might appear to be straightforward. However, Africa's lingering challenges make them complex. In the context of COVID-19, there is, however, a clear message that it is no longer business as usual for Africa. As one commentator noted to $\mathrm{C} 1$ :

The world will be different after Covid-19 and if African governments do not support their own innovators, then Africa will continue to be a begging bowl when the rest of the world is moving ahead. We need to embrace African solutions to our problems. It is now time for Africans to solve their own problems.

\section{Conclusion}

Our study has revealed the potential of the African diaspora to contribute significantly to knowledge production, innovation, and development in their COOs through the process of transnationalism. We have highlighted the need for the creation of an 
enabling environment if this is to be actualised. In this conclusion we reflect on some of the barriers to this realisation which Zimbabwe and indeed Africa would need to address to make the environment conducive and propose ideas for the way forward.

Our findings indicated the existence of restrictive government systems which limit the ability of talented individuals to realise their potential for innovation within a Zimbabwe context. The study therefore confirmed the findings of Thondhlana \& Madziva (2018) regarding the inflexibility of some African government systems which limit or prohibit rather than facilitate diaspora contributions. According to Chand (2016: 278), brain circulation 'requires that the $\mathrm{COO}$ of the immigrants take proactive steps to leverage the diaspora, and listen to their concerns while creating a partnership that actively benefits both sides'. For example, African countries can allow dual nationality as a way of encouraging brain circulation. This is a lesson that can be learned from the experiences of South Asian diasporas (for example, India and Pakistan) as a way of incentivising the successful diasporans to provide more help to the $\mathrm{COO}$ while they feel integrated within both communities (COO and COR) (Chand 2016).

In addition to government mistrust, diasporans often face resistance from colleagues in the country of origin. For example, while the $\mathrm{C} 5$ project was largely successful in its implementation, it faced resistance from academics who remained in Zimbabwe who were put off by the perceived red carpet treatment of their 'unpatriotic' counterparts:

These are people who deserted the universities at the slightest sign of economic problems. Now that IOM has dangled a USD 50 per day on top of all expenses that are covered, they are now back to mock us. It is better if IOM can give us those incentives in appreciation to our resilience in remaining and holding fort when our traitor colleagues left for greener pastures.

Other local academics felt that:

The amount that they are paid per day is worth ten times my monthly salary. it is extremely unfair to reward these Diaspora professionals considering that they are already paid a fortune in foreign land. One would expect that they would cede their per diem to us in the same manner that some of them donated second-hand books and equipment.

Such colleagues preferred that, instead of coming back to Zimbabwe, diaspora academics should network with local staff and students through mutual exchange programmes to widen their knowledge and experiences. This is perhaps a sentiment to consider for future programmes.

Our study showed that Africans lack confidence in their abilities and those of their African colleagues to innovate - a 'foreign is better' syndrome which needs to be tackled if Africa is to realise its potential. As noted by $\mathrm{C} 1$, Africans did not readily 
accept the products that he was marketing under his label, but were quick to accept the same products under a foreign label. This lack of confidence in the innovative abilities of fellow Africans is what Matthews (2017) refers to as 'colonisation of the mind'. This is linked to what is seen as a 'Pull Him/Her Down' (PHD) syndrome and 'Anti-Progress' mindset.

Our findings revealed the tendency to bring down emerging innovators in Africa, resulting in many going into forced migration as well as discouraging diasporans from contributing to developing the COO. For example, $\mathrm{C} 1$ and $\mathrm{C} 3$ reflected about the many entrepreneurs in foreign countries who are African and are part of teams designing cars, aircraft, and medical science while their COOs do not benefit.

Additionally, the dilemma of the requirement to reveal trade/product secrets versus threat to national security is another noted prohibitive factor. In this regard, in relation to diaspora innovations the $\mathrm{COO}$ authorities may require the innovators to disclose classified or confidential information about their products as part of the screening process, failing which this may be considered a threat to national security punishable by imprisonment. However, as expressed by $\mathrm{C} 1$ and $\mathrm{C} 3$ this requirement is tantamount to theft of ideas or intellectual property.

Further, most of our cases reported the lack of funding as a key consideration in deciding to migrate and consequently settle in host countries. Programmes for leveraging the diaspora, for example $\mathrm{C} 5$, were also curtailed of sustainable funding.

In further pondering ways of addressing these challenges, lessons from the lived experiences of our participants and the emerging patterns are worth noting. Overall transnationalism could be more productive if it were more systematised. In doing so we acknowledge that migrants' mobility and practices are not homogenous as determined by transnational mobility and practices which intersect with diverse socio-political aspects, including race, age, gender, class, and settlement status (Westwood \& Phizacklea 2000). Our proposals are therefore meant to contribute to existing debates in a way that can encourage further conversations about how the diaspora can be leveraged to more strategically and systematically contribute to knowledge creation, innovation, and development through attitude and behaviour change of all stakeholders and partners.

One pattern that emerged from our findings is of bringing innovations back home. The outcomes of C1's and C3's innovation journeys demonstrate that, in the absence of funding and a clear strategy for supporting innovators, going to countries where there may be more favourable policies and better developed ecosystems would be beneficial, particularly in the context of globalisation and discourses of global citizenship. Such a move can be beneficial to both the country of origin and country of destination where the innovator, as has been demonstrated by both $\mathrm{C} 1$ and $\mathrm{C} 3$, may have strong intentions to benefit the homeland (Saxenian 2006). In this way, mobility 
of human capital helps to facilitate international knowledge flows from developed to developing economies (Chand 2019).

Another emerging pattern involves working in partnership with local communities. In this regard, tapping into indigenous knowledge systems through collaboration with the $\mathrm{COO}$ is a potentially viable model, as demonstrated by C2's experiences. This model enables the innovator to promote indigenous knowledges in the host nation while benefiting the country of origin through the use of the innovation; a compensation system including payment for products, contribution toward community development projects, and charitable activity (for example, supporting the education of disadvantaged children). Similarly, Chand (2016: 278) notes how 'older engineers and entrepreneurs in both the Chinese and the Indian communities now help finance and mentor younger co-ethnic entrepreneurs'. Our study has further shown that collaborating with local communities as an insider catalyses the process of knowledge sharing, innovation, and development.

A further pattern relates to the development of formal structures for knowledge exchange through partnerships at national level. One of the advantages of the global circulation of human capital is that diasporans are well placed to facilitate useful collaborations between institutions in their COO and those in the COR (DeVoretz 2006, Chand 2016). Indeed, the academic route of promoting knowledge production through partnerships has been tried in Zimbabwe with relative success. Such a model is popular in the context of the internationalisation of higher education where partnerships enable cross-fertilisation and cost sharing through funding schemes which usually call for such collaborations. C4 who works at a top UK university has been able to link her host university to institutions in Zimbabwe in productive ways. As noted above, this has led to the collaborative development of educational policy. Similarly, the success of the diaspora temporary return project (C5) can be attributed to its structured, problem-based, and participatory approach. For Radwan \& Sakr (2018: 522) such initiative could be further strengthened by:

stimulating bilateral training programmes, joint postgraduate degrees and distance-learning programmes. Joint graduate programmes, where students might even take courses at a foreign institution, should enable African students to obtain their degrees from their home institutions. Foreign universities should be encouraged to support with financing and even faculty full-fledge educational and scientific programmes at African research institutions.

More generally, the existing literature supports initiatives that lead to knowledge production and institution building or strengthening. In this regard, studies have argued that, while remittances count as one of the major sources of financial flows in terms of development impact in developing countries as compared to other financial 
flows (for example, aid and private capital), knowledge and institution building have a more lasting impact (Kapur \& McHale 2005). This way, the global circulation of high-skill labour from poor economies to rich ones and back is opening new possibilities for economic development, whereby talented citizens who go abroad to continue their studies and work in the developed economies, use their own global networks to help build new establishments in their home countries (Chand 2016). It should, however, be noted that both schemes depend on availability of funding. As noted by C5, the diaspora temporary return project could not be sustained because government could not take it over. Such a dependency on external funding presents the risk of the hegemonic effect resulting from the funding culture of funders dictating how the project should be conducted.

\section{References}

African Union (2016), The Revised Migration Policy Framework for Africa and Plan of Action (20182027). https://au.int/sites/default/files/newsevents/workingdocuments/32718-wd-english_revised_ au_migration_policy_framework_for_africa.pdf

Basch, L., Glick Schiller, N. \& Szanton Blanc, C. (1994), Nations Unbound: Transnational Projects, Postcolonial Predicaments, and Deterritorialized Nation States (Basel, Gordon and Breach).

Bauder, H., (2006), 'Origin, Employment Status and Attitudes Towards Work: Immigrants in Vancouver', Work, Employment and Society, 20(4): 709-29. https://doi.org/10.1177/0950017006069810

Boly, A., Coniglio, N., Prota, F. \& Seric, A. (2014), 'Diaspora Investments and Firm Export Performance in Selected Sub-Saharan African Countries', World Development, 59: 422-33. https://doi.org/10.1016/j.worlddev.2014.02.006

Boyo, T.M. (2013), 'The African Brain Drain and the Social Impact of Skilled Migration', MA thesis University of Toronto.

Cerna, L. \& Chou, M.H. (2014), 'The Regional Dimension in the Global Competition for Talent: Lessons From Framing the European Scientific Visa and Blue Card', Journal of European Public Policy, 21(1): 76-95. https://doi.org/10.1080/13501763.2013.831114

Chand, M. (2016), 'Leveraging the Diaspora for Africa's Economic Development', Journal of African Business, 17(3): 273-90. https://doi.org/10.1080/15228916.2016.1160856

Chand, M. (2019), 'Brain Drain, Brain Circulation, and the African Diaspora in the United States', Journal of African Business, 20(1): 6-19. https://doi.org/10.1080/15228916.2018.1440461

Chetsanga, C.J. \& Muchenje, T.B. (2003) An Analysis of the Cause and Effect of the Brain Drain in Zimbabwe (Harare, Scientific and Industrial Research and Development Centre).

Chikanda, A. (2005), 'Skilled Health Professionals' Migration and its Impact on Health Delivery in Zimbabwe' (Working Paper 4; Oxford, Centre on Migration, Policy and Society, Oxford University). https://doi.org/10.1080/13691830600610064

Chimanikire, D.P. (2005), Zimbabwe Migration: Part Two (Trade and Development Studies Centre, issue 30; Harare, Trades Centre).

Chrysostome, E.V. \& Molz, R. (eds) (2014), Building Businesses in Emerging and Developing Countries: Challenges and Opportunities (Abingdon, Routledge). https://doi.org/10.4324/9780203080665

Crush, J. (2002), 'The Global Raiders: Nationalism, Globalization and the South African Brain Drain', Journal of International Affairs, 56: 147-72. 
DeVoretz, D. (2006), A History of Canadian Recruitment of Highly Skilled Immigrants: 1980-2001 (Discussion Paper, 2197; Bonn, Institute for the Study of Labour).

Ehrkamp, P. \& Leitner, H. (2006), 'Rethinking Immigration and Citizenship: New Spaces of Migrant Transnationalism and Belonging', Environment and Planning A, 38(9): 1591-7. https://doi.org/10.1068/a38349

Erel, U. (2010), 'Migrating Cultural Capital: Bourdieu in Migration Studies', Sociology, 44(4): 642-60. https://doi.org/10.1177/0038038510369363

Faist, T. (2010), 'Diaspora and Transnationalism: What Kind of Dance Partners?', in R. Bauböck \& T. Faist (eds) Diaspora and Transnationalism Concepts, Theories and Methods (Amsterdam, Amsterdam University Press), 9-34.

Fogtman, A., Müller, C. \& Oketch, M. (2020), 'How to Set Up a Space Nation on the Example of Ghana', in A. Froehlich (ed.) Space Fostering African Societies: Developing the African Continent through Space, Part 1 (Cham, Springer), 71-82. https://doi.org/10.1007/978-3-030-32930-3_6

Garwe, E.C. \& Thondhlana, J. (2018), 'Higher Education Systems and Institutions, Zimbabwe', in Encyclopedia of International Higher Education Systems and Institutions (Dordrecht, Springer). https://doi.org/10.1007/978-94-017-9553-1_479-1

Hynes, P. (2003), The Issue of 'Trust' or 'Mistrust' in Research with Refugees: Choices, Caveats and Considerations for Researchers (Geneva, UNHCR).

International Monetary Fund (2016), World Economic Outlook: Subdued Demand: Symptoms and Remedies, October (Washington, DC, International Monetary Fund). https://doi.org/10.5089/9781513519333.081

IOM (2017), 'Migration and Migrants: A Global Overview', in World Migration Report 2018 (Geneva, International Organization for Migration).

Johnson, J.M. \& Regets, M.C. (1998), International Mobility of Scientists and Engineers to the United States-Brain Drain or Brain Circulation? (SRS Issue Brief; Arlington, VA, National Science Foundation).

Kahn, K.B. (2018), 'Understanding Innovation', Business Horizons, 61(3): 453-60. https://doi.org/10.1016/j.bushor.2018.01.011

Kajunju, A. (2013), 'Africa’s Secret Weapon: The Diaspora'. http://edition.cnn.com/2013/11/01/opinion/ africas-secret-weapon-diaspora/ [Accessed 10 July 2020].

Kapur, D. \& McHale, J. (2005), Give us Your Best and Brightest: The Global Hunt for Talent and Its Impact on the Developing World (Washington, DC, Center for Global Development).

Kuznetsov, Y. (ed.) (2006), Diaspora Networks and the International Migration of Skills: How Countries Can Draw on Their Talent Abroad (Washington, DC, The World Bank). https://doi.org/10.1596/978-0-8213-6647-9

Levitt, P. (2001), 'Transnational Migration: Taking Stock and Future Directions', Global Networks, 1(3): 195-216. https://doi.org/10.1111/1471-0374.00013

Madziva, R. \& Thondhlana, J. (2017), 'Provision of Quality Education in the Context of Syrian Refugee Children in the UK: Opportunities and Challenges', Compare: A Journal of Comparative and International Education, 47(6): 942-61. https://doi.org/10.1080/03057925.2017.1375848

Madziva, R., McGrath, S. \& Thondhlana, J. (2014), 'The Hidden Face of Discrimination in the Global Labour Market: The Case of Zimbabwean Highly Skilled Migrants in the UK', in Invisible Visible Minority: Confronting Afrophobia and Advancing Equality for People of African Descent and Black Europeans in Europe European Network Against Racism (Brussels, European Network Against Racism),140-56.

Madziva, R., Siwale, J. \& Thondhlana, J. (2018), 'Exploring Gender and Diaspora Investment Among Diaspora Women in the UK', in African Diaspora Direct Investment (Cham, Palgrave Macmillan), 211-37. https://doi.org/10.1007/978-3-319-72047-0_10 
Mandiyanike, D. (2014), Zimbabwe's Return Migrants—Before \& After Challenges (SAMP Policy Brief, 29; Southern African Migration Programme).

Matthews, S. (2017), 'Colonised Minds? Post-development Theory and the Desirability of Development in Africa', Third World Quarterly, 38(12): 1-14. https://doi.org/10.1080/01436597.2017.1279540

Mbembe, A. (2016), 'Decolonizing the University', Arts and Humanities in Higher Education, 15(1): 29-45. https://doi.org/10.1177/1474022215618513

McCance, T.V. McKenna, H.P. \& Boore, J.R. (2001), 'Exploring Caring Using Narrative Methodology: An Analysis of the Approach', Journal of Advanced Nursing, 33(3): 350-6. https://doi.org/10.1046/j.1365-2648.2001.01671.x

McGrath, S., Madziva, R. \& Thondhlana, J. (2017), 'Rethinking the Employability of International Graduate Migrants: Reflections on the Experiences of Zimbabweans with Degrees from England', Journal of Further and Higher Education, 41(2): 238-59. https://doi.org/10.1080/0309877X.2015.1062853

McGregor, J., (2014), 'Sentimentality or Speculation? Diaspora Investment, Crisis Economies and Urban Transformation', Geoforum, 56: 172-81. https://doi.org/10.1016/j.geoforum.2014.07.008

Ndlovu-Gatsheni, S.J. (2015), 'Decoloniality as the Future of Africa', History Compass, 485-96. https://doi.org/10.1111/hic3.12264

Okolie, A.C., (2003), 'Producing Knowledge for Sustainable Development in Africa', Higher Education, 46(2): 235-60. https://doi.org/10.1023/A:1024717729885

Osaghae, O.G. (2018), 'Understanding Diaspora Transnationalism', in: D. Hack-Polay \& J. Siwale (eds), African Diaspora Direct Investment: Establishing the Economic and Socio-cultural Rationale (Palgrave Macmillan), 13-41. https://doi.org/10.1007/978-3-319-72047-0_2

Pasura, D. (2012), 'A Fractured Transnational Diaspora: The Case of Zimbabweans in Britain', International Migration, 50(1): 143-61. https://doi.org/10.1111/j.1468-2435.2010.00675.x

Radwan, A. \& Sakr, M. (2018), 'Exploring 'Brain Circulation' as a Concept to Mitigate Brain Drain in Africa and Improve EU-Africa Cooperation in the Field of Science and Technology', South African Journal of International Affairs, 25(4): 517-29. https://doi.org/10.1080/10220461.2018.1551151

Riddle, L., Hrivnak, G.A. \& Nielsen, T.M. (2010), 'Transnational Diaspora Entrepreneurship in Emerging Markets: Bridging Institutional Divides', Journal of International Management, 16(4): 398-411. https://doi.org/10.1016/j.intman.2010.09.009

Robertson, S.L. (2006), 'Brain Drain, Brain Gain and Brain Circulation', Globalisation, Societies and Education, 4(1): 1-5. https://doi.org/10.1080/14767720600554908

Safran, W. (1991), 'Diasporas in Modern Societies: Myths of Homeland and Return', Diaspora: A Journal of Transnational Studies, 1(1): 83-99. https://doi.org/10.1353/dsp.1991.0004

Santiago, M.A.L. (2019), 'Diaspora International Family Entrepreneurs: No Place Like Home', DLSU Business \& Economics Review, 28(3): 34-46.

Saxenian, A. (2006), The New Argonauts: Regional Advantage in a Global Economy (Cambridge MA, Harvard University Press). https://doi.org/10.2307/j.ctv1dp0ttd

Shachar, A. (2006), 'The Race for Talent: Highly Skilled Migrants and Competitive Immigration Regimes', New York University Law Review, 81: 148.

Siwale, J. (2018), 'Mapping of Diaspora Direct Investment: Critical Areas of Investment', in D. Hack-Polay \& J. Siwale (eds) African Diaspora Direct Investment: Establishing the Economic and Socio-cultural Rationale (Cham, Palgrave Macmillan), 63-85. https://doi.org/10.1007/978-3-319-72047-0_4

Stabinsky, D. \& Brush, S.B. (eds) (1996), Valuing Local Knowledge: Indigenous People and Intellectual Property Rights (Washington, DC, Island Press).

Tevera, D.S. \& Crush, J. (2003), The New Brain Drain from Zimbabwe (Migration Policy Series, 29; South African Migration Project). 
Thondhlana, J. (2020), 'On Becoming a Skilled Migrant: Towards Habitus Transformation Through Higher Education', Educational Review, 72(2): 242-61.

https://doi.org/10.1080/00131911.2018.1505712

Thondhlana, J. \& Madziva, R. (2018), 'Skilled Migrant African Women of Faith and Diaspora investment', in African Diaspora Direct Investment (Cham, Palgrave Macmillan), 239-64. https://doi.org/10.1007/978-3-319-72047-0_11

Thondhlana, J., Madziva, R. \& McGrath, S. (2016), 'Negotiating Employability: Migrant Capitals and Networking Strategies for Zimbabwean Highly Skilled Migrants in the UK', The Sociological Review, 64(3): 575-92. https://doi.org/10.1111/1467-954X.12373

Thondhlana, J., Abdulrahman, H., Garwe, E.C. \& McGrath, S. (2020), 'Exploring the Internationalization of Zimbabwe's Higher Education Institutions Through a Decolonial Lens: Postcolonial Continuities and Disruptions', Journal of Studies in International Education, p.1028315320932319. https://doi.org/10.1177/1028315320932319

Tung, R.L. (2004), Introduction to 'China's Leading Internet Guru Charles Zhang, Chairman of SOHU. com Inc., on How the Internet has Changed the world's Most Populous Nation', Academy of Management Executive, 18(4): 143-5. https://doi.org/10.5465/ame.2004.15268751

Tung, R.L., (2008), 'Brain Circulation, Diaspora, and International Competitiveness', European Management Journal, 26(5): 298-304. https://doi.org/10.1016/j.emj.2008.03.005

UNICEF (2011), Education in Emergencies and Post-crisis Transition. Evaluation Report (New York, UNICEF).

Westwood, S. \& Phizacklea, A. (2000), Trans-nationalism and the Politics of Belonging (Hove, Psychology Press).

Zegeye, A. \& Vambe, M. (2006), 'Knowledge Production and Publishing in Africa', Development Southern Africa, 23(3): 333-49. https://doi.org/10.1080/03768350600843010

\section{Notes on the authors}

Dr Juliet Thondhlana is Associate Professor in Education and Migration at the University of Nottingham. She researches and publishes on the interaction of language, migration, refugee education, higher education, employability, gender, and entrepreneurship as well as the role of faith. More recently she has conducted research on the internationalisation of higher education in the UK and in Zimbabwe, culminating in the development of a national policy framework for the internationalisation of higher education in Zimbabwe.

ORCID ID: https://orcid.org/0000-0002-4065-5103

juliet.thondhlana@nottingham.ac.uk

Dr Roda Madziva is Assistant Professor in Sociology, at the University of Nottingham. Her research centres around migration and forced displacement, exploring the ideological assumptions that frame discourses of inclusion and exclusion, and the extent to which they reveal hierarchies of human worth. She has published many journal articles and book chapters on migrant and refugee integration.

ORCID ID: https://orcid.org/0000-0003-2485-787x

Roda.Madziva@nottingham.ac.uk 
Professor Evelyn Chiyevo Garwe is the Deputy Chief Executive Officer for the Zimbabwe Council for Higher Education. She is a keen researcher and practitioner with expertise and experience in quality assurance, and strategic and project management. She researches around transformation and quality issues in all aspects of higher education including: leadership and governance, research, internationalisation, gender, and financing. She is also interested in the ways that inclusive education shapes the narratives regarding various stakeholders for example students, academics, vulnerable societies, etc.

ORCID ID: https://orcid.org/0000-0002-6111-8622

garweec@gmail.com

To cite the article: Juliet Thondhlana, Roda Madziva and Evelyn Chiyevo Garwe (2021), 'What can the African diaspora contribute to innovation and knowledge creation? The case study of Zimbabwean innovators', Journal of the British Academy, 9(s1): 101-125.

DOI https://doi.org/10.5871/jba/009s1.101

Journal of the British Academy (ISSN 2052-7217) is published by The British Academy, 10-11 Carlton House Terrace, London, SW1Y 5AH

www.thebritishacademy.ac.uk 
